\title{
Systematic review of the effectiveness of homoeopathy in the treatment of autism spectrum disorder
}

\author{
Vibha Saxena', Gish Chacko², Udit Saxena ${ }^{3}$ \\ 'State KGK Homoeopathic, Medical College and Hospital, Moradabad, India; ${ }^{2}$ Speech Language Pathology, MAA Institute of Speech and Hearing, \\ Osmania University, Hyderabad, India; ${ }^{3}$ Head of Department (Speech and Hearing), MAA Institute of Speech and Hearing \& MAA ENT Hospital, \\ Hyderabad, India
}

Purpose: Over the years there is a significant increase in Autism Spectrum Disorder (ASD), yet there is no standard medical treatment available for this population. Homoeopathy as reported in literature can prove to be a boon for ASD treatment as in homoeopathy patients are prescribed medicine based on specific symptoms in light of associated physical and mental aspect. A systematic review of literature was required to put together the reported information on the relation between homoeopathy and ASD. This work reviews all the related literature in-depth.

Methods: Literature on the concerned issue was searched from databases like Scopus, PubMed, ScienceDirect, JASTOR, Google Scholar, PsycINFO (psychology and psychiatry literature), and ERIC (Education Resources Information Center).

Results: In total, 19 published articles were found on the investigation of using homoeopathy in the treatment of ASD. Seventeen studies showed that homoeopathy can be effective in the treatment of ASD. Result of 1 study was inconclusive and 1 more study found homoeopathy to be not suitable in treating ASD.

Conclusions: Most reports support the use of homoeopathy in the treatment of ASD. They describe that homoeopathy efficiently control ASD symptoms and also supplements other therapies used in the treatment of ASD. Few authors suggested otherwise too.

Keywords: Homoeopathy, Autism Spectrum Disorder, Treatment, Therapies

\section{INTRODUCTION}

Autism is a developmental disorder of neurological origin that affects normal functioning of the sufferer in the society. They majorly lack social interaction, have verbal and non-verbal communication deficit and show repetitive/limited behavior. Autism mostly erupts in childhood and may change during the course of life [1-6]. Autism differs from person to person in terms of severity and combination of symptoms. Symptoms may range from mild to severe and often change over time $[1,2,5]$.

The term "Autism" was first used by Leo Kanner, an American Scientist in 1943 for describing children who showed reduced social interest $[4,7,8]$. Since 2013, Autism along with Asperger Syndrome, Pervasive Developmental Disorder-Not Otherwise Specified and Childhood Disintegrative Disorder are grouped under a term "Autism

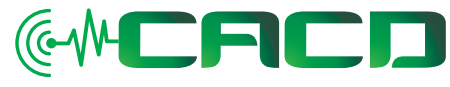

Received: January 22, 2021

Revision: April 15, 2021

Accepted: April 20, 2021

Correspondence:

Dr Vibha Saxena

State KGK Homoeopathic Medical College and Hospital, Moradabad, India Tel: +04023871213

Fax: +04023271213

E-mail:drvibha.homoeo@gmail.com

(C) 2021 The Korean Association of SpeechLanguage Pathologists

This is an Open Access article distributed under the terms of the Creative Commons Attribution NonCommercial License (https://creativecommons.org/ licenses/by-nc/4.0/) which permits unrestricted noncommercial use, distribution, and reproduction in any medium, provided the original work is properly cited. 
Spectrum Disorder (ASD)" by Diagnostic and statistical manual of mental disorder (Version-5) [9]. The term ASD was approved by International Classification of Diseases in its 11th version [10].

World Health Organization (2019) reported global ASD prevalence to be at 1 in every 160 children. In developed country like the United States of America recorded an alarming increase in its prevalence from 1 in 500 children (a decade ago) to 1 in 68 (in 2014) and 1 in 54 (in 2016) [7,10,12]. In developing country like India, it is ranged to be between $0.15 \%$ to $1.01 \%[13,14]$. Prevalence of ASD in many low to middle income countries remains unknown.

ASD has shown to have multi-factorial genetic and non-genetic etiologies [5-7,15]. Recent researches have an indicated strong genetic basis of ASD [5-8,15] Sibling with ASD and twins are at high risk of developing ASD. Some non-genetic high-risk factors of ASD are advanced paternal age, intrauterine exposures to teratogenic drugs, birth complications (such as trauma and ischemia/hypoxia) and heavy metal exposure $[2,7,15-17]$

ASD is usually diagnosed in the first 2-3 years of life as most characteristics of the disorder manifest by that time. In some cases, child develops normally till toddler-age and ASD symptoms emerge thereafter. There is no specific medical test available to diagnose this condition [2]. Diagnostic and statistical manual of mental disorder (Version-5) provided guidelines for the standard diagnosis of ASD and also defined its severity range $[8,9]$. Clinically, ASD is diagnosed using various developmental and behavioral tools, questionnaires and/or checklists such as Childhood Autism Rating Scale, Gilliam Autism Rating Scale, Autism Behavior Checklist, Autism Spectrum Quotient, Social Responsiveness Scale, Pervasive Developmental Disorder Behavior Inventory, Autism Diagnostic Interview-Revised and Autism Diagnostic Observation Schedule and Autism Behavior Inventory [2,10,18]. Diagnosing ASD is sometimes difficult as it may co-exist with conditions like attention-deficit/hyperactivity disorder, obsessive compulsive disorder, anxiety or depression, or conduct disorder [2].

Autism is a lifelong condition. Management of ASD is very challenging considering the versatility of symptoms, the fact that symptoms may revoke and severity of symptoms may change over time. ASD management involves multidisciplinary approach with the aim to reduce symptoms, improve cognitive ability, communication and daily living skills \& to maximize the ability of child to function and participate in the community.
Heterogeneity in terms of symptoms is very high in ASD and as such management of ASD is patient specific. Applied Behavior Analysis, Antecedent-based Intervention, Cognitive Behavioral Intervention, Education of Autistic and Related Communication Handicapped Children, Naturalistic Interventions, Functional Communication Training, Occupational Therapy, Pivotal Response Training, Speech Therapy\& Technological-aided Instruction and Intervention are the various management strategies currently available for treating ASD. Depending upon the symptoms one or a combination of many treatments mentioned above are given to the individual with ASD. However, these treatments mainly focus more on communication and sensory issues, academics, behavioral modification and adaptive living $[2,10,18]$.

Talking about the medical management, despite of the advancement in the modern medicine system (Allopathy) there is no $100 \%$ cure for ASD. Some allopathic medications are helpful in containing certain ASD symptoms like irritability, aggression, repetitive behavior and hyperactivity. However, there is limitation in the use of allopathic medication for ASD. It comes from the indications that long term usage of allopathic medication, in case of persisting symptoms (which is very common in ASD), may cause side-effects and induce drug-dependency which may not be safe for this population especially when they cannot express their problem [19-21].

Apart from Allopathy, there are several global and country based indigenous medicine systems. Some of them are Homoeopathy (Originated in Germany now practiced globally. It is the second largest used system of medicine after Allopathy), Herbalism, Acupuncture, Ayurveda (Originated in India now practiced globally), Chelation Therapy, Kinesiology, Ozone Therapy, Reflexology, Massage Therapy, Iridology, Unani, (Islamic medicinal system and Chinese Traditional Medicine (Originated and practiced in China). Term "Naturopathy" is the term used to describe them collectively. In literature on the treatment of ASD, there is no mention of any other Naturopathic medicine system in the treatment of ASD except Homoeopathy.

Homoeopathy medicine system was founded by German physician Dr Samuel Hahnemann. Interestingly, Dr Samuel Hahnemann was initially a practitioner of Allopathy and in fact the one who coined the term "Allopathy". Homoeopathy and its traits are very different from other medicine systems. Homoeopathy medicine system is based on the principle of "Similia Similibus Curentur" which means "Likes Cure Likes". This is known as "Law of Similia". Homoeopathy believes on 
the existence of vital force which on derangement leads to the development of disease. Correction of deranged vital force can only be possible when a medicine with similar symptoms and strong in nature work on the deranged vital force and produce artificial disease which is similar and stronger than the natural disease, so by the virtue of "Natures Law of Cure" artificial medicinal disease will annihilate the original disease and induce cure. Homoeopathy follows a holistic approach of healing, wherein the physician treats the patient as a whole and select the medicine thorough investigation of physical, mental and behavioral aspect of the individual. This is called "Individualized Holistic Treatment".

Therapeutic or curative power of homeopathic medicines is evaluated through "Drug Proving". This is done by administering potentised medicine to the healthy individuals (Provers) of different ages and sex. The curative effect of the medicine is then scientifically analyzed by recording the changes in "Provers" This is to estimate the effect of remedies on human body. Based on the results of "Drug Proving" medicines are prescribed. Homeopathic medicines act dynamically on the vital force to induce changes, which are similar to those brought about by disease. Thus, to achieve cure, medicines are selected appropriately in a way that disease picture (patients' symptoms) is similar to medicinal picture.

ASD is presented by versatile symptoms in various domains like social interaction, restrictive behavior, communication, sensory input, memory, sleep and skills. These symptoms are outward presentation of internal derangement of the individual. Homoeopathy works at the dynamic plane of individual and can bring about the cure by annihilation of ASD symptoms. In Homoeopathy, numbers of medicines are available that can help in containing a wide range of symptoms as appear in ASD population. Every ASD child is unique in terms of characteristic symptoms. Specific homoeopathic medicines can be selected after identifying uncommon, rare, peculiar and characteristic symptom of the patient with the help of proper case taking.

At the same time, risk associated with homoeopathic treatment is minimal, as it has no side effects even when used for long. This is because homoeopathic medicines are potentised following the "Law of Minimum" of homoeopathy. This law states that smaller the quantity of homoeopathy medicine higher will be the curative power. Potentisation of homoeopathic drugs is a mathematico-mechanical process. It is done for the reduction of crude, inert or poisonous medical substances by which the dynamic energy, latent in crude sub- stances, is aroused and liberated for use as medicine. That is why, homeopathic medicines act on the dynamic plane to develop artificial disease which extinguish on itself since the quantity of drug is very small; hence it does not induce any ill effect.

Though, homoeopathy presents strong prospect to treat ASD (based on its treatment traits). Currently the efficacy of homoeopathy in treating ASD is poorly understood. One of the reasons for that being the fact that reports on the treatment of ASD using homoeopathy is limited and scattered. Therefore, to address the gap we reviewed the available literature on this issue in order to highlight the success and limitation of homoeopathy in the treatment of ASD.

\section{METHODS}

Literature on the concerned issue was searched from databases like Scopus, PubMed, ScienceDirect, JASTOR, Google Scholar, PsycINFO (psychology and psychiatry literature), and ERIC (Education Resources Information Center). Different combinations of relevant terms and keywords related to ASD and homoeopathic treatment were used as search strategy (Table 1). We also go through the reference lists of all the articles included in this review in order to identify additional studies and reviewed clinical trials related to homoeopathy for ASDs to identify corresponding articles. Inclusion and exclusion criteria of article was adapted from preferred reporting items for systematic reviews and meta-analyses (2009)

\begin{tabular}{ll} 
Table 1. Terms and keywords used for the literature search \\
\hline S.No & Terms and keywords \\
\hline 1 & Autism \\
2 & Autism spectrum disorder \\
3 & Autistic \\
4 & Homoeopathy \\
5 & Homeopathy \\
6 & Homoeopathic \\
7 & Homeopathic \\
8 & Homoeopathic treatment \\
9 & Homeopathic treatment \\
10 & Homoeopathic medicine \\
11 & Homeopathic medicine \\
12 & Treatment using homeopathy \\
13 & Alternative medicine \\
14 & Alternative treatment \\
\hline
\end{tabular}




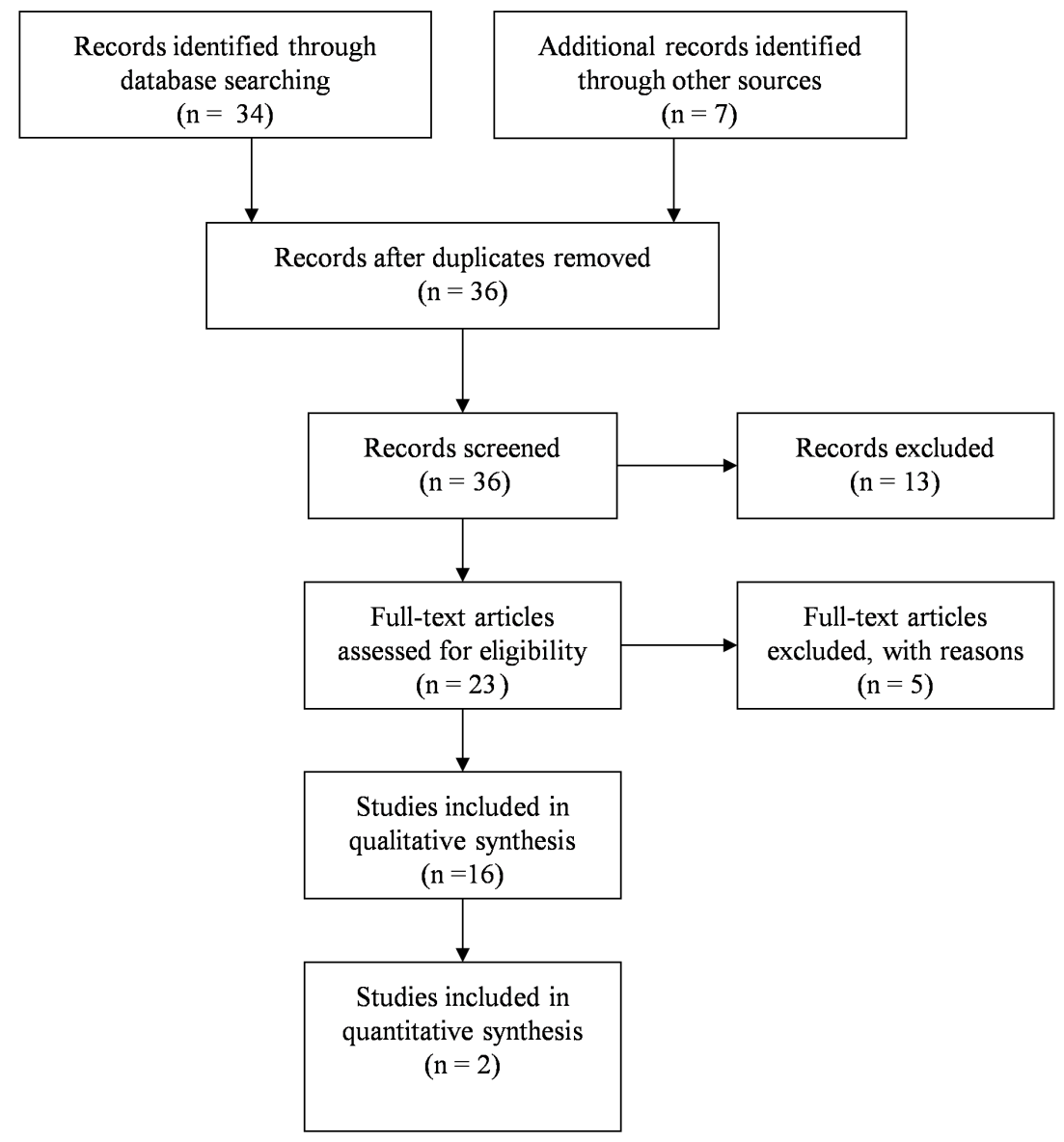

Figure 1. Representation of preferred reporting items for systematic reviews and meta-analyses adopted for selecting articles in this review (adapted from Moher, Liberati, Tetzlaff and Altman 2009).

and represented in Figure 1 [22]. As there were only limited studies on the issue, related information was also collected from health-newsletters, health-magazine and websites of various homoeopathic physicians, caretaker/parents of individuals with ASD and multi-disciplinary professionals involved in the management of ASD.

As mentioned earlier terminologies for this clinical population keep evolving till ICD has standardize it to ASD [which include autism and its less severe conditions such as Asperger syndrome and pervasive developmental disorder not otherwise specified]. In order to avoid discrepancies, in this review we have denote this population using the terms as was used by the authors in their respective reports.

\section{RESULTS}

A rigorous literature search on finding the published articles on the issue of understanding the effectiveness of homoeopa- thy in the treatment of ASD showed the existence of 19 scientific investigation on the issue. Summary of the 19 article and homoeopathy medicines used in the treatment of ASD by respective authors are also mentioned in Table 2 . There were 17 reports that support the usage homoeopathy in the treatment of ASD. ASD is a multi-symptomatic disorder and may need intervention from multiple professionals (as mentioned in introduction), these studies suggested that homoeopathy not only was effective in treating the symptoms of ASD but also provide support to the effects of other therapies/treatment/ interventions given to ASD. On the contrary, one study suggested otherwise and found homoeopathy to be not efficient in treating ASD. One study was inconclusive in deciding whether homoeopathy was effective or not in the treatment of ASD. Comparative analysis of all the 19 studies is done/shown in Table 3. All the19 studies are described/elaborated in discussion. 
Table 2. Summary of the articles

\begin{tabular}{|c|c|c|c|c|}
\hline S.No & Authors & Participants & Results & Medicine used \\
\hline 1 & Robinson (2001) & $\begin{array}{l}12 \text { adults having autism } \\
\text { (Age: } 24 \text { to } 43 \text { years) }\end{array}$ & $\begin{array}{l}\text { Homoeopathic treatment resulted in } \\
\text { the improvement of behavior in some } \\
\text { while deterioration in others }\end{array}$ & Secretin \\
\hline 2 & $\begin{array}{l}\text { Weber and } \\
\text { Newmark (2007) }\end{array}$ & & $\begin{array}{l}\text { No supportive evidence to use } \\
\text { homoeopathy in autism }\end{array}$ & Not mentioned \\
\hline 3 & Rossingol (2009) & & $\begin{array}{l}\text { Inconsistent or inconclusive study of } \\
\text { any level or studies reporting no } \\
\text { improvement }\end{array}$ & Not mentioned \\
\hline 4 & $\begin{array}{l}\text { Fonseca, Bolognani, } \\
\text { Durão, Souza, } \\
\text { Castro, Accioly } \\
\text { et al. (2008) }\end{array}$ & $\begin{array}{l}30 \text { ASD children (Age: }<7 \\
\text { years) }\end{array}$ & $\begin{array}{l}\text { Positive interference of homoeopathic } \\
\text { medication in the cognitive, motor } \\
\text { and behavioral performance }\end{array}$ & $\begin{array}{l}\text { Arnica Montana, Thebaicum, Stramonium, } \\
\text { Arsenicum Album, Carcinosinum and Natrium } \\
\text { Muriaticum }\end{array}$ \\
\hline 5 & Rajlakshami (2008a) & $\begin{array}{l}5 \text { autistic children (Age: } 4 \\
\text { and } 9 \text { years) }\end{array}$ & $\begin{array}{l}\text { Quick recovery in mild autistic children } \\
\text { and induce hope of betterment in } \\
\text { severe autism following } \\
\text { homoeopathic intervention }\end{array}$ & $\begin{array}{l}\text { Belladona, Lycopodium, Arsenicum Album, Silicea, } \\
\text { Calcarea Carbonica, Nux Vomica, Coffea, } \\
\text { Staphysagria, Stramonium, Glonoine, Natrium } \\
\text { Muriaticum, Hyoscyamus, Kali Carbonicum, } \\
\text { Antimonium Tart and Pulsatilla }\end{array}$ \\
\hline 6 & Rajlakshami (2008b) & $\begin{array}{l}6 \text { ASD children (Age: } 3 \text { to } 12 \\
\text { years) }\end{array}$ & $\begin{array}{l}\text { Homoeopathic treatment not only } \\
\text { improve the general condition of } \\
\text { ASD children but also brings out his } \\
\text { latent savant ability }\end{array}$ & $\begin{array}{l}\text { Ignatia, Argentum Nitricum, Hyoscyamus, } \\
\text { Tuberculinum, Cautiscum, Pulsatilla, Staphysagria, } \\
\text { Silicea, Kali Carbonicum, Coffea, Sulphur and } \\
\text { Stramonium }\end{array}$ \\
\hline 7 & Rajlakshami (2011) & A case study & $\begin{array}{l}\text { Homoeopathic remedies work very } \\
\text { well }\end{array}$ & $\begin{array}{l}\text { Calcare Carbonica, Silica, Lycopodium and Nux } \\
\text { Vomica }\end{array}$ \\
\hline 8 & Rajlakshami (2015) & $\begin{array}{l}4 \text { cases. } \\
\text { First and 2nd case had ASD } \\
\text { with ADHD and Rett } \\
\text { syndrome, respectively. } \\
\text { Third with Pervasive } \\
\text { Developmental Disorder- } \\
\text { Not Otherwise Specified } \\
\text { and 4th with severe } \\
\text { autism. }\end{array}$ & $\begin{array}{l}\text { Homoeopathic treatment has } \\
\text { accelerated the process of recovery } \\
\text { and optimizes the effects of speech } \\
\text { therapy and occupational therapy }\end{array}$ & $\begin{array}{l}\text { Pulsatilla, Belladona, Lycopodium, Calcarea } \\
\text { Carbonica, Silicea, Sanicula, Zincum Met, Natrum } \\
\text { Carbonicum and Manganum Aceticum }\end{array}$ \\
\hline 9 & Rajlakshami (2016) & $\begin{array}{l}6 \text { case studies of ASD } \\
\text { children }\end{array}$ & Positive effect of homoeopathy & $\begin{array}{l}\text { Argentum Nitricum, Lycopodium, Pulsatilla, Silicea, } \\
\text { Kali Carbonicum and Stramonium }\end{array}$ \\
\hline 10 & Rajlakshami (2018) & 40 ASD children & $\begin{array}{l}\text { Significant post-homoeopathic } \\
\text { treatment improvement in autistic } \\
\text { conditions }\end{array}$ & $\begin{array}{l}\text { Pulsatilla, Silicea, Lycopodium, Agaricus, Belladona, } \\
\text { Staphysagria, Nux Vomica, Sepia, Calcarea } \\
\text { Carbonica, Zincum Metallicum, Stramonium, } \\
\text { Glononine, Arsenic Album, Natrum Muriaticum, } \\
\text { Calcarea Phosphoricum, Nux Moschata, Colocynth, } \\
\text { Hyoscyamus, Lac Caninum, Coffea, Bacillinum, } \\
\text { Natrum Sulph, Aethusa, Kali Brom, Kali } \\
\text { Carbonicum, Hepar Sulph, Natrum Carbonicum and } \\
\text { Argentum Nitricum }\end{array}$ \\
\hline 11 & $\begin{array}{l}\text { Gupta, Saxena, } \\
\text { Malhotras and } \\
\text { Juneja (2010) }\end{array}$ & $\begin{array}{l}25 \text { autistic children (Age: } 4 \\
\text { to } 14 \text { years) }\end{array}$ & $\begin{array}{l}\text { Homoeopathic treatment resulted in } \\
\text { significant improvement in } 60 \% \text { of } \\
\text { mild to moderate autistic children } \\
\text { and } 38 \% \text { of severe autistic children }\end{array}$ & $\begin{array}{l}\text { Belladona, Hyoscyamus, Vertrum Album, Kali Brom, } \\
\text { Phosphorus, Silicea, Bufo, Sepia, Calcarea Phos, } \\
\text { Sulphur, Baryta Carbonica, Tuberculinum, Coffea, } \\
\text { Kali Phos, Thuja and Passiflora }\end{array}$ \\
\hline
\end{tabular}


Table 2. Continued

\begin{tabular}{|c|c|c|c|c|}
\hline S.No & Authors & Participants & Results & Medicine used \\
\hline 12 & $\begin{array}{l}\text { Gupta, Saxena, } \\
\text { Juneja, and } \\
\text { Malhotra (2011) }\end{array}$ & $\begin{array}{l}10 \text { ASD children (Age: } 9 \text { to } \\
14 \text { years) }\end{array}$ & $\begin{array}{l}\text { Marked improvement was reported } \\
\text { after using homoeopathy }\end{array}$ & $\begin{array}{l}\text { Belladona, Hyoscyamus, Vertrum Album, Kali Brom, } \\
\text { Phosphorus, Silicea, Stramonium, Bufo, Sepia, } \\
\text { Calcarea Phos, Sulphur, Baryta Carbonica, } \\
\text { Tuberculinum, Coffea, Kali Phos, Thuja, Hepar } \\
\text { Sulph, Zincum Metallicum, Tarentula, Ignatia, } \\
\text { Carcinocin and Lachesis }\end{array}$ \\
\hline 13 & $\begin{array}{l}\text { Gupta, Saxena, } \\
\text { Juneja, and } \\
\text { Malhotra (2013) }\end{array}$ & $\begin{array}{l}4 \text { ASD children (Age: 5-10 } \\
\text { years) }\end{array}$ & $\begin{array}{l}\text { Effective control in behavioral ASD } \\
\text { symptoms by giving two sets of } \\
\text { homoeopathic medicines }\end{array}$ & $\begin{array}{l}\text { Phosphorus, Thuja, Sulphur, Silicea, Calcarea Phos, } \\
\text { Tuberculinum, Santoninum, Calcarea Carbonica, } \\
\text { Veratrum Album, Tuberculinum, Belladonna, Bufo } \\
\text { Rana, Hyoscyamus, Tarentula and Natrum } \\
\text { Muriaticum }\end{array}$ \\
\hline 14 & Gupta (2015) & $\begin{array}{l}10 \text { ASD children (Age: } 9 \text { to } \\
14 \text { years) }\end{array}$ & $\begin{array}{l}\text { Strong effectiveness of homoeopathic } \\
\text { treatment in ASD }\end{array}$ & $\begin{array}{l}\text { Belladona, Hyoscyamus, Vertrum Album, Kali Brom, } \\
\text { Silicea, Stramonium, Bufo, Sepia, Calcarea Phos, } \\
\text { Sulphur, Baryta Carbonica, Tuberculinum, Coffea, } \\
\text { Kali Phos and Thuja }\end{array}$ \\
\hline 15 & Barvalia (2011a) & 92 autistic patient & $\begin{array}{l}\text { Statistical lowering of autistic load } \\
\text { following homoeopathic } \\
\text { interventions }\end{array}$ & Borax, Cocculus, Nux Vomica and Stramonium \\
\hline 16 & Barvalia (2011b) & A case study & $\begin{array}{l}\text { Homoeopathic treatment was } \\
\text { successful }\end{array}$ & $\begin{array}{l}\text { Carcinosinum, Stramonium, Hyoscyamus, Nux } \\
\text { Vomica, Tarentula, Phosphorus, Tuberculinum, } \\
\text { Natrum Mur, Opium, Borax, Veratrum Album, } \\
\text { Calcarea Carbonica, Medorrhinum, Cina, Lyssin, } \\
\text { Plumbum Met, lodum, Lachesis, Mercurius } \\
\text { Solubilis and Syphillinum }\end{array}$ \\
\hline 17 & $\begin{array}{l}\text { Barvalia, Oza, } \\
\text { Daftary, Patil, } \\
\text { Agarwal, and } \\
\text { Mehta (2014a) }\end{array}$ & $\begin{array}{l}60 \text { autistic children (Age } \\
<12 \text { years) }\end{array}$ & $\begin{array}{l}\text { Significant improvement in behavioural } \\
\text { dysfunction, sensory impairment, } \\
\text { communication difficulty, cognitive } \\
\text { ability and hyperactivity following } \\
\text { homoeopathy }\end{array}$ & $\begin{array}{l}\text { Carcinosinum, Stramonium, Medorrhinum, Nux } \\
\text { Vomica, Lyssin, Lachesis, Zincum Metallicum, } \\
\text { Hyoscyamus, Veratrum Album, Tuberculinum } \\
\text { Bovinum, Cina, Tarentula Hispanica, Baryta } \\
\text { Carbonica, Phosphorus, Calcarea Carbonica, } \\
\text { Silicea, Natrum Muriaticum, Calcarea Silicate, } \\
\text { Opium, Lycopodium, Causticum, Natrum } \\
\text { Phosphoricum and Plumbum Metallicum }\end{array}$ \\
\hline 18 & Barvalia (2014b) & $\begin{array}{l}2 \text { autistic children (Age } 5 \text { to } \\
9 \text { years) }\end{array}$ & $\begin{array}{l}\text { Sequential administration of } \\
\text { homeopathic medicines, following } \\
\text { the principles of Organon, can bring } \\
\text { about improvement in autistic } \\
\text { features }\end{array}$ & $\begin{array}{l}\text { Tarantula Hispanica, Tuberculinum, Stramonium, } \\
\text { Natrum Phosphoricum, Lyssin And Carcinosin }\end{array}$ \\
\hline 19 & Smits (2011) & A case study & Positive effect of homoeopathy & Not mentioned \\
\hline
\end{tabular}

\section{DISCUSSION}

Dr. Paul Herscu and Dr. Amy Rothenberg (naturopathic physicians with specialty in classical homoeopathy) have extensively illustrated homoeopathy treatment in ASD [23-27]. Dr Herscu as cited in [25] emphasized on the treatment of autistic patients with homoeopathy based on three reasons. First is the ineffectiveness of conventional psychotic medicine used in the treatment of autism. These medicines only calm the patients but do not cure. Second comes from his clinical experience, according to which he says that accurate homoeopathic treatment takes the case in right direction. In addition, the degree of autism does not correspond to the degree of the cure which means that mild cases may receive only partial benefit while some severe cases may get greatly improved with homoeopathic treatment. Third is the evidence of supplemen- 
Table 3. Comparative analysis of the studies included in this review

\begin{tabular}{|c|c|c|}
\hline $\begin{array}{l}\text { Studies that found homoeopathy to be effective in the } \\
\text { treatment on ASD }\end{array}$ & $\begin{array}{l}\text { Studies that found homoeopathy is not } \\
\text { effective in the treatment on ASD }\end{array}$ & Inconclusive studies \\
\hline 1. Robinson (2001) & 1. Weber and Newmark (2007) & 1. Rossingol (2009) \\
\hline \multicolumn{3}{|l|}{$\begin{array}{l}\text { 2. Fonseca, Bolognani, Durão, Souza, Castro, Accioly et al. } \\
\text { (2008) }\end{array}$} \\
\hline \multicolumn{3}{|l|}{ 3. Rajlakshami (2008a) } \\
\hline \multicolumn{3}{|l|}{ 4. Rajlakshami (2008b) } \\
\hline \multicolumn{3}{|l|}{ 5. Rajlakshami (2011) } \\
\hline \multicolumn{3}{|l|}{ 6. Rajlakshami (2015) } \\
\hline \multicolumn{3}{|l|}{ 7. Rajlakshami (2016) } \\
\hline \multicolumn{3}{|l|}{ 8. Rajlakshami (2018) } \\
\hline \multicolumn{3}{|l|}{ 9. Gupta, Saxena, Malhotra and Juneja (2010) } \\
\hline \multicolumn{3}{|l|}{ 10. Gupta, Saxena, Juneja and Malhotra (2011) } \\
\hline \multicolumn{3}{|l|}{ 11. Gupta, Saxena, Juneja, and Malhotra (2013) } \\
\hline \multicolumn{3}{|l|}{ 12. Gupta (2015) } \\
\hline \multicolumn{3}{|l|}{ 13. Barvalia (2011a) } \\
\hline \multicolumn{3}{|l|}{ 14. Barvalia (2011b) } \\
\hline \multicolumn{3}{|l|}{ 15. Barvalia, Oza, Daftary, Patil, Agarwal and Mehta (2014a) } \\
\hline \multicolumn{3}{|l|}{ 16. Barvalia (2014b) } \\
\hline 17. Smits (2011) & & \\
\hline
\end{tabular}

tary (positive) effect of homoeopathic treatment on other therapies (such as speech therapy, sensory integration therapy, diet and nutrition) given to manage autistic patients. Dr Herscu reported that proving of alcoholus medicine in the treatment of children with autism and found its good effect [23-25].

Herscu and Rothenberg [24] demonstrated "Cycles and Segments" model and elaborated its clinical application in the treatment of children and adults suffering from pervasive developmental delay and autism. This model concentrates on focused case taking, efficient case analysis and integrated study of materia medica in concise way. Rothenberg [26] discussed a tool "Map of Hierarchy" in the treatment of Autism through a case study. Map of Hierarchy aids in the selection of medicine and monitor the progress of patient. Surprisingly, Dr Hersu and Dr Rothenberg did not undertake any experimental study so far in spite of their vast clinical practice of treating ASD patients with homoeopathic medicine.

According to Opioid Excess Theory, peptides formed due to in-complete digestion of certain foods induce morphine-like activity which may manifest as symptom of autism when concentrated in brain [28]. Secretin, a duodenal enzyme aids in the metabolism of peptides, was found to reduce this activity and useful in bringing down the autistic features [29]. Robinson [30] prescribed secretin based on the "Opioid Excess Theory" and reported its effects in 12 adults having autism (Age: 24 to 43 years). Pre- and post-treatment Childhood Autism Rating Scale (CARS [31]. Scores suggested improvement of behavior in some while deterioration in others. He also suggested undertaking a study comparing Placebo vs Secretin.

Shalts [32] claimed that homoeopathy work for autistic children when prescription is based on individualization and integrated with other therapies such as cranial therapy, sensory integration techniques, occupational therapy, and behavioral therapy. On the contrary, Weber, et al. [33] found no supportive evidence to use homoeopathy in autism while reviewing the use of complementary and alternative (CAM) treatment such as craniosacral therapy and other manipulative therapies, Reiki and other energy medicine modalities, biofeedback, and traditional Chinese medicine in ADHD and autism. However, there was no elaboration specific to homoeopathy. Rossingol (2009) has mentioned homoeopathic treatment as D-grade (troublingly inconsistent or inconclusive study of any level or studies reporting no improvement) just on the basis of the conclusion made by Robinson (2001) [30,34]. He was reviewing various treatment modes for ASD. In my view, these 
conclusions on the use of homoeopathy in the treatment of ASD are inappropriate as they weren't based on any scientific investigation or adequate research evidences.

Fonseca, et al. [35] conducted a study on thirty children with autism (Age: $<7$ years). Homoeopathic remedies were prescribed on the basis of symptom-similarity. They used medicines in 30C or $200 \mathrm{C}$ potency and integrated organotherapy (a modality of isopathic treatment in which diluted and agitated homologous human body tissues are used to correct dysfunctions) to homoeopathic treatment in order to amplify its action and the field of operation. Psycho-Educational Profile-Revised [36] was used for the pre- and postevaluation of cognitive, motor and behavioral performance in autistic patients. Results suggested a positive interference of homoeopathic medication in the cognitive, motor and behavioral performance (decrease in aberrant behavior \& better social and familiar integration) of autistic children. They further stressed on the early and longer use of medication for better outcome

Rajlakshami (2008a; 2008b; 2011; 2015; 2016; 2018) has done elaborative work on understanding the effectiveness of homoeopathic treatment in ASD [37-42]. In 2008a, she used homoeopathic medication in 5 autistic children (Age: 4 and 9 years). She prescribed homoeopathic medicine specific to the child using classical homoeopathic approach. Autism Treatment Evaluation Checklist was used for assessing child before and after the treatment [43]. Post homoeopathic treatment she found reduced hyperactivity, anxiety and temper-tantrums \&improved emotions, attention span, tolerance, motor skills, sleep pattern, social behavior and communication skills in children with autism. She concluded that homoeopathic treatment brings quick recovery in mild autistic children and induce hope of betterment in severe autism. In a similar study, Rajalakshmi [38] selected 6 autistic children (Age: 3 to 12 years), out of them, 4werecategorized as high functioning autism and rest 2 as low functioning autism with associated mental retardation. She found 200C potency to be best suited to these children as they responded very well and faster without any homoeopathic aggravations. She also insisted on early initiation of treatment for better results. Autistic children were assessed with the help of Autism Behavior Composite Checklist and Profile [44]. Savant skills (special skill or abilities) disappeared once they start to speak or with improvement in other skills. Author hypothesized that homoeopathic treatment not only improve the general condition of autistic children but also brings out his latent savant ability. However, fur- ther research is needed to establish this fact. Rajlakshmi [39] elaborated a case study of autistic child and suggested that in some complicated cases homoeopathic remedies work very well.

Rajlakshmi [40] investigated the potential of homoeopathic treatment along with other interventions like occupational and speech therapies given as part of multidisciplinary approach to manage ASD. First and 2nd case had ASD with ADHD and Rett syndrome, respectively. Third was diagnosed with Pervasive Developmental Disorder-Not Otherwise Specified and the 4th with severe autism. Out of these four cases, three were non-verbal and one had no meaningful speech. Children were given single homoeopathic remedy after individualization of the patient. Speech, language and communication skills, sociability, sensory/cognitive awareness, health/ physical and behavioral issues of each case were compared one year after the homoeopathic treatment using ATEC. Significant positive changes were reported in each domain. She concluded that homoeopathic treatment has accelerated the process of recovery and optimizes the effects of speech therapy and occupational therapy. She also suggested that the direction of homoeopathic treatment should be from intellectual/cognitive domain to the emotional and from the emotional to the physical.

Rajlakshmi [41] evaluated the role of homoeopathic treatment in conjunction with neuropsychological therapies in the management of ASD. She summarized six case studies of ASD children who have shown improvement in the area of sensory dysfunction, behavior, procedural memory and communication skills with homoeopathic treatment. She observed that homoeopathic treatment fastens the process of learning skills and sensory integration. Additionally, she found that homoeopathic treatment reduced temper tantrums and aggressive self-injurious behaviors such as head banging. Rajlakshmi [42] reported descriptive case studies of 40 ASD children in which she adopted similimum approach to prescribe homoeopathic medicine. On comparing pre- and post- treatment ATEC scores, significant improvement was found in ASD children. In this study she also reviewed the academic performance of these children and stressed that homoeopathic medicines helped them in reaching optimal level of scholastic functioning and in turn integrate them into the mainstream. The various studies reported by Rajalakshmi have shown good effectiveness of homoeopathy in the treatment of ASD. She has adopted different types of methodology in her investigations; this strengthens the reliability, validity 
and generalization of the results she presented.

Gupta, et al. (2010, 2011, 2013, and 2015) \& Barvalia, et al. (2011a, 2011b, and 2014a) are other investigators who have done significant work on understanding relation of homoeopathy and ASD [45-51]. Gupta, et al [45] conducted a study on 25 autistic children (Age: 4 to 14 year) to assess the effectiveness of homoeopathic medicines in the treatment of ASD. Authors developed an Autistic Children Psychological Analysis Assessment questionnaire for the assessment of autistic symptoms at the start and end of 18 months homoeopathic treatment. They selected 7 parameters for psychological assessment and 10 parameters for clinical assessment of symptoms in autistic children. On the basis of the severity of symptoms, they categorized the autistic children into two groupsgroup A and group B. Autistic children of severity from mild to moderate degree (group A) were given single homoeopathic medicine as per classical approach while severe autistic children (group B) were prescribed with frequently repeated multiple homoeopathic medicines. Significant improvement was found in $60 \%$ of mild to moderate autistic children and $38 \%$ of severe autistic children. Their results also showed high potencies $(1 \mathrm{M}, 10 \mathrm{M})$ to be more effective when sensory symptoms were prominent and low/moderate potencies (30C, 200C) when physical symptoms (such as fidgety, involuntary soiling of clothes etc).

Gupta, et al. [46] studied homoeopathy in 10 ASD children (Age: 9 to 14 years). This time they prescribed them a set of constitutional and intercurrent or complementary homoeopathic medicines as per symptoms and effectiveness. CARS and Autistic Children Psychological Analysis Assessment questionnaire were used to assess the treatment progress of the autistic children. Results were found to be encouraging as there weremarked reduction in autistic features and significant improvement in specific behavior.

Further, et al. [47] reported effective control in behavioral ASD symptoms by giving two sets of homoeopathic medicines, constitutional and miasmatic, selected on the basis of specific symptoms of 4 ASD children (Age: 5-10 years). The study demonstrated significant improvement of autistic behavioral and social symptoms as per the analysis of CARS and Vineland Social Maturity Scale Test (Singh, Pandey and Agarwal, 2019). Similarly, Gupta [48] suggested effectiveness of homoeopathic treatment in 10 ASD children (Age: 9 to 14 years).

Barvalia [49] 92 autistic patient on the basis of dominant symptoms; 60 and 32 patients were studied with respect to cognitive ability and sensory issues, respectively. He found statistically lowering of autistic load in both the groups following homoeopathic interventions through sequential use in a juridicious way. Barvalia [50] illustrated homoeopathic treatment of an autistic child in details. Barvalia, et al. [51] demonstrated significant improvement in behavioral dysfunction, sensory impairment, communication difficulty, cognitive ability and hyperactivity in 60 autistic children (Age $<12$ years). Barvalia [51] has given illustration of 2 cases with the demonstration of homoeopathic approach in management of ASD. In all the studies of Mr. Barvalia, assessment and comparison of the treatment response was evaluated using ATEC, CARS, Social Quotient scores (calculated through Vineland Social Maturity Scale) and Autistic Hyperactivity Scale (as cited in Barvalia, et al. 2011a, 2014a) [49,51].

In addition to the model and tool developed by Dr Hersu and Dr Rothenberg (mentioned earlier) there are other homoeopaths who have developed certain specific treatment approaches for ASD, for example, CEASE Therapy and Sine wave method. Dr Tinus Smits [52] suggested a new approach "Complete Elimination of Autism Spectrum Expression therapy" (CEASE therapy) to treat ASD. CEASE therapy is developed using the concept of isotherapy which involve step-wise prescription of homoeopathic medicine based on the all the assumed causative factor of autism. In addition, he also advised to provide orthomolecular medicine (such as magnesium, vitamin C, zinc, fish oil, etc.) in order to support healing process. A case study of Pervasive Developmental DisorderNot Otherwise Specified showing positive effect of CEASE therapy was reported [53].

Kantor [54] highlighted possible difficulty in using classical homoeopathy alone for the multifactorial condition like autism and introduced Sine wave method to cure autism with homoeopathy. This method offers a wide range of tools which contains prevailing homoeopathic approaches and other (than homoeopathy) remedies including lanthanides, gases, gem essences, meditative proving remedies, color and sound remedies \& traditional Chinese medicine. Its effectiveness was demonstrated through 8 case studies. However, the tool described by Kantor is not yet reported and/or validated by others.

\section{CONCLUSION}

In this review we have mentioned the various approaches, models and tools adopted by different homoeopathic physi- 
cians around the world to treat ASD. All these have pointed out a definitive role of homoeopathy in the treatment of ASD. Research investigations, though limited, suggested the same. However, the quantum of research done in the area doesn't match the increasing ASD population. It makes it necessary to undertake in-depth studies about the issue with a strong methodology including large sample size and reliability check.

\section{CONFLICT OF INTEREST}

On behalf of all authors, the corresponding author states that there is no conflict of interest.

\section{REFERENCES}

1. American Psychological Association (n.d.). Autism spectrum disorder. Retrieved December 2019; from: https://www.apa.org/topics/autism/.

2. Centers for Disease Control and Prevention (n.d.). Autism spectrum disorder (ASD). Retrieved December 2019; from: https:// www.cdc.gov/ncbddd/autism/index.html.

3. Copeland JN.What is autism spectrum disorder? Retrieved December 2019, from: https://www.psychiatry.org/patients-families/autism/what-is-autism-spectrum-disorder\#: :text=Autism\%20 spectrum\%20disorder\%20(ASD)\%20is,are\%20different\%20in\%20 each\%20person.

4. Park HR, Lee JM, Moon HE, Lee DS, Kim BN, Kim J, et al. A short review on the current understanding of autism spectrum disorders. Exp Neurobiol. 2016;25:1-13.

5. Pendergrass S, Girirajan S, Selleck S. Uncovering the etiology of autism spectrum disorders: genomics, bioinformatics, environment, data collection and exploration, and future possibilities. Pac SympBiocomput. 2014;422-426.

6. Samsam M, Ahangari R, Naser S. Pathophysiology of autism spectrum disorders: revisiting gastrointestinal involvement and immune imbalance. World J Gastroenterol. 2014;20:9942-9951.

7. Faras $\mathrm{H}, \mathrm{Al}$ Ateeqi, Tidmarsh L. Autism spectrum disorders. Annals of Saudi Medicne. 2010;30:295-300.

8. Udhya J, Varadharaja MM, Parthiban J. Autism disorder (AD): An updated review for paediatric dentists. J Clin Diagn Res. 2014; 8:275-279.

9. American Psychiatric Association Diagnostic and statistical manual of mental disorders (DSM-V). Arlington, VA: American Psychiatric Publishing. 2013.

10. Subramanyam AA, Mukherjee A, Dave M, Chavda K. Clinical Practice Guidelines for Autism Spectrum Disorders. Indian J Psychiatry. 2019;61(Suppl 2):254-269.

11. World Health Organization. Autism spectrum disorders: Key facts. Retrieved December 2019, from: https://www.who.int/news- room/fact-sheets/detail/autism-spectrum-disorders. 2019.

12. Maenner MJ, Shaw KA, Baio J, WashingtonA, Patrick M, DiRienzo $\mathrm{M}$, et al. Prevalence of autism spectrum disorder among children aged 8 years-autism and developmental disabilities monitoring network, 11 sites, United States, 2016. MMWR Surveil Summar. 2020;69:1-12.

13. Raina SK, Chander V, Bhardwaj AK, Kumar D, Sharma S, Kashyap $\mathrm{V}$, et al. Prevalence of autism spectrum disorder among rural, urban, and tribal children (1-10 Years of Age). J Neurosci Rural Pract. 2017;8:368-374.

14. Rudra A, Belmonte MK, Soni PK, Banerjee S, Mukerji S, Chakrabarti B. Prevalence of autism spectrum disorder and autistic symptoms in a school-based cohort of children in Kolkata, India. Autism Res. 2017;10:1597-1605.

15. Taylor MJ, Rosenqvist MA, Larsson H, Gillberg C, D'Onofrio BM, Lichtenstein $\mathrm{P}$, et al. Etiology of autism spectrum disorders and autistic traits over time. JAMA Psychiatry. 2020; e200680.

16. Modabbernia A, Velthorst E, Reichenberg A. Environmental risk factors for autism: an evidence-based review of systematic reviews and meta-analyses. Mol Autism. 2017;8:13.

17. Park HR, Lee JM, Moon HE, Lee DS, Kim BN, Kim J, et al. A short review on the current understanding of autism spectrum disorders. Exp Neurobiol. 2016;25:1-13.

18. Fernandopulle N. Measurement of autism: A review of four screening measures. Indian J Psychol Med. 2011;33:5-10.

19. Coury DL. Review: Little evidence of clear benefit for most medical treatments for children with autism spectrum disorders. Evidence-based Mental Health. 2011;14:105.

20. LeClerc S, Easley D. Pharmacological therapies for autism spectrum disorder: A review. P T. 2015;40:389-397.

21. McPheeters ML, Warren Z, Sathe N, Bruzek JL, Krishnaswami S, Jerome, et al. A systematic review of medical treatments for children with autism spectrum disorders. Pediatrics. 2011;127:e1312e1321.

22. Moher D, Liberati A, Tetzlaff J, Altman DG. The PRISMA statement: preferred reporting items for systematic reviews and metaanalyses. PLoS Med. 2009;6:e1000097.

23. Herscu P. Provings: With a proving of alcoholus. New England School of Homeopathy: USA. 2000.

24. Herscu P, Rothenberg A. An evening of homeopathy: The cycles and segments approach for homeopathic practice [Video]. https://nesh.com/what-is-dr-paul-herscus-cycles-segments-approach/an-evening-of-homeopathy/. 2011.

25. Latchis S. Homeopathy and autism: Report by Paul Herscu Homeopathy Today. 2001;21:20-21.

26. Rothenberg A. The map of hierarchy and a case of autism. Naturopathic doctors news \& review. 2011; Retrieved January 2020, from: https://ndnr.com/neurology/the-map-of-hierarchy-and-acase-of-autism/

27. Rothenberg A. (n.d.). The homeopathic treatment of autism. Retrieved January 2020, from:https://www.nhcmed.com/furtherreading/topic-treating-challenging-children/the-homeopathictreatment-of-autism.html 
28. Shattock $\mathrm{P}$, Whiteley P. Biochemical aspects in autism spectrum disorders: updating the opioid-excess theory and presenting new opportunities for biomedical intervention. Expert OpinTher Targets. 2002;6:175-183.

29. Horvath K, Stefanatos G, Sokolski KN, Wachtel R, Nabors L, Tildon JT. Improved social and language skills after secretin administration in patients with autistic spectrum disorders. Journal of the Association for Academic Minority Physicians: the official publication of the Association for Academic Minority Physicians. 1998;9:9-15.

30. Robinson TW. Homeopathic secretin in autism: a clinical pilot study. The British Homoeopathic Journal. 2001;90:86-91.

31. Chlebowski C, Green JA, Barton ML, Fein D. Using the childhood autism rating scale to diagnose autism spectrum disorders. J Autism dev disord. 2010;40:787-799.

32. Shalts E. The American institute of homeopathy handbook for parents: a guide to healthy treatment for everything from colds and allergies to ADHD, obesity, and depression. San Francisco, CA: Jossey-Bass- A Wiley Imprint. 2005

33. Weber W, Newmark S. Complementary and alternative medical therapies for attention-deficit/hyperactivity disorder and autism. Pediatr Clin North Am. 2007;54:983-995.

34. Rossignol DA. Novel and emerging treatments for autism spectrum disorders: A systematic review. Annals of Clinical Psychiatry: official journal of the American Academy of Clinical Psychiatrists. 2009;21:213-236.

35. De Menezes Fonseca GR, Bolognani FA, Durão FF, Souza KM, de Castro M, Accioly C, et al. Effect of homeopathic medication on the cognitive and motor performance of autistic children. International Journal of High Dilution Research-ISSN 1982-6206. 2008;7:63-71.

36. CrippaA, Molteni M. Further empirical data on the psychoeducational profile-revised (PEP-R): reliability and validation with the Vineland adaptive behavior scales. J Autism Dev Disord. 2010; 40:334-341.

37. Rajalakshmi MA. Role of Homoeopathy in the management of autism: Study of effects of homoeopathic treatment on the autism triad. The Internet Journal of Alternative Medicine. 2008a;6(1).

38. Rajalakshmi MA. New dimensions in the treatment of autism with homeopathy. The Internet Journal of Alternative Medicine. 2008b;7(2).

39. Rajalakshmi MA. A case of autism: A case for homeopathy. Homoeopathic Links. 2011;24:39-43.

40. Rajalakshmi MA. Healing autism with homeopathy in synergy with other therapies. Hpathy Ezine. 2015.

41. Rajalakshmi MA. Homeopathic treatment as an adjunct to neuropysychological therapies in children with autism spectrum disor- ders. International Journal of Public Mental Health and NeuroSciences. 2016;2:13-18.

42. Rajalakshmi MA. Homeopathic treatment as an aid to inclusive integration of children with autism spectrum disorders. 2018; Retrieved January 2020, from: https://www.researchgate.net/publication/327098328_Homeopathic_Treatment_as_an_Aid_to_Inclusive_Integration_of_Children_with_Autism_Spectrum_Disorders.

43. Mahapatra S, Vyshedsky D, Martinez S, Kannel B, Braverman J, Edelson SM, et al. Autism Treatment Evaluation Checklist (ATEC) Norms: A "Growth Chart" for ATEC Score Changes as a Function of Age. Children (Basel, Switzerland). 2018;5:25.

44. Riley AM. Autistic Behavior: Composite Checklist and Profile/20 to 1, Communication Skill Builders. 1986.

45. Gupta N, Saxena RK, Malhotra AK, Juneja R. Homoeopathic medicinal treatment of Autism. Indian Journal of Research in Homeopathy. 2010;4:19-28.

46. Gupta N, Saxena RK, Malhotra AK, Juneja R. Homoeopathic Approach for the Management of Symptoms of Autism Spectrum Disorder: A Four Years of Experience of Controlled Clinical Study (Conference paper). Conference: LIGA, New Delhi. Retrieved January 2020, from: 2011; https://www.researchgate.net/publication/302963275_Homoeopathic_Approach_for_the_Management_of_Symptoms_of_Autism_Spectrum_Disorder_A_Four_ Years_of_Experience_of_Controlled_Clinical_Study

47. Gupta N, Saxena RK, Malhotra AK, Juneja R. Effectiveness of homeopathy in four autism spectrum disorder cases. Homoeopathic Links. 2013;26:256-261.

48. Gupta N. Effectiveness of homeopathic therapy in autism spectrum disorder. 2015; (Conference paper). South Asia International Autism Conference At: India Habitat Centre, New Delhi, India. Retrieved January 2020.

49. Barvalia P. Autism Spectrum Disorder- Holistic Homoeopathy, part - I. Homoeopathic Links. 2011a;24:31-38.

50. Barvalia P. Autism Spectrum Disorder- Holistic Homoeopathy, part - II. Homoeopathic Links. 2011b;24:92-96.

51. Barvalia P, Oza PM, Daftary AH, Patil VS, Agarwal VS, Mehta AR. Effectiveness of homoeopathic therapeutics in the management of childhood autism disorder. Indian Journal of Research in Homeopathy. 2014;8:147-159.

52. Smits T. Autism: beyond despair, CEASE therapy. Haarlem, The Netherlands: Emryss. 2010.

53. Smits T. A case of PDD-NOS treated with cease therapy. Homoeopathic Links. 2011;24:188-191.

54. Kantor JM. Cyclical Remedy complexes: their origin within traditional chinese medicine and relevance for miasmatic theory. Homoepathic Links. 2017;30:202-207. 